\title{
FUNCTIONAL AND PASTING PROPERTIES OF PRODUCTS OF WHITE AND YELLOW CASSAVA
}

\author{
Onyeneke, Esther-Ben \\ Department of Nutrition and Dietetics, Faculty of Health Science, Imo State University \\ Email: estyninika@gmail.com
}

\begin{abstract}
This study evaluated the pasting properties of selected products; fufu, garri and tapioca made from yellow cassava (Manihot utilisima Crantz) and white cassava (Manihot dulcis Crantz) products. The cassava products were obtained from the National Root Crops Research Institute, Umudike, Abia State and was processed in food science and technology and nutrition and dietetics laborstory, Imo state university. The functional and pasting result showed that among the studied finished cassava products, the fermented cassava flour had the highest water absorption capacity (WAC) $4.4 \mathrm{~g} / \mathrm{g}$ as compared to values of $3.75 \mathrm{~g} / \mathrm{g}$ for garri and $2.85 \mathrm{~g} / \mathrm{g}$ for tapioca.The water absorption capacities of the white cassava products were in the range of $2.79 \pm 0.01$ to $4.34 \pm 0.14 \mathrm{~g} / \mathrm{g}$ with white cassava tapioca having the least value $(2.79 \pm 0.0 \mathrm{~g} / \mathrm{g})$ and the white cassava flour having the highest value (4.34£0.14). Some significant differences $(p<0.05)$ existed between the water absorption capacities value of the match pairs (similar products) of white and yellow cassava varieties, with the exception of the garri samples. The oil absorption capacities (OAC) of the yellow cassava products were in the range of $1.94 \pm 0.03$ to $2.91 \pm 0.01 \mathrm{~g} / \mathrm{g}$ with yellow cassava tapioca having the least value $(1.94 \pm 0.03 \mathrm{~g} / \mathrm{g})$ e and the yellow cassava flour having the highest value $(2.91 \pm 0.01 \mathrm{~g} / \mathrm{g})$. The oil absorption capacities of the white cassava products were in the range of $1.95 \pm 0.01$ to $2.94 \pm 0.10 \mathrm{~g} / \mathrm{g}$ with white cassava tapioca having the least value (1.95 \pm 0.01$)$ and white cassava flour having the highest value $(2.94 \pm 0.10 \mathrm{~g} / \mathrm{g})$. All the match pairs (similar products) of the yellow and white cassava showed significant differences $(p<0.05)$ in the oil absorption capacity of the cassava product with exception of the tapioca samples. The bulk density $(B D)$ value of the yellow cassava products and white cassava products were in the range of $0.48 \pm 0.05$ to $0.54 \pm 0.0 \mathrm{~g} / \mathrm{ml}$ and $0.47 \pm 0.04$ to $0.55 \pm 0.02 \mathrm{~g} / \mathrm{ml}$ respectively. There was no significant difference $(p>0.05)$ between all the pair similar products from the yellow and white cassava varieties with regards to the BD. Garri samples had the highest water absorption capacity $(4.36 \mathrm{~g} / \mathrm{g}, 4.34 \mathrm{~g} / \mathrm{g}$ ) and (7.5\%) solubility. Also, the result revealed that yellow cassava fufu (flour) had the highest (5084 RVU) values in peak viscosity, trough viscosity (2590 RVU), breakdown viscosity (2494 RVU) and final viscosity (3500 RVU) but not in setback viscosity, peak time (min) and pasting temperature $\left({ }^{0} \mathrm{C}\right.$ )
\end{abstract}

Keywords: Tapioca, Bulk Density, Garri, Pasting

https://dx.doi.org/10.4314/jafs.v17i1.1 


\section{INTRODUCTION}

Cassava (Manihot esculenta Crantz) also called Yuca by South America, Manioc by Gulf of Mexico and Mandiola by Western Central Brazil is a woody shrub of the euphorbiaceae (spurge family), native to South America. In terms of colour of the tuber pulp, two major varieties-white and yellow, exist worldwide (Oduro, 1984). Starch is the major component in cassava tuber and its physicochemical properties, such as the hydration rate, pasting properties and gel strength, are the most concern of cassava products processors (Eke et al., 2012). Although the cassava tubers and changes of its properties during storage have been widely studied, the changes of cassava tuber varieties over time during storage focusing on the starch fine structure and related to pasting properties are limited (Nwancho et al., 2014). In particular, cassava produces high amounts of starch compared to other crops such as rice and maize (Charles et al., 2004). Given the increasing trends of production of cassava crop, exploitation of starch from cassava is a necessary option to cater for the increased demand especially in the dietary and industrial sectors (FAOSTAT, 2008).Functionality has been defined as any property that affects the utilization of a product governed by four major factors, which are colour, flavor (aroma), texture and nutritive value (Eriksson et al., 2013). Functional properties refer to the overall behavior or performance of proteins in food stuff and reflect the various interactions that proteins take part (Onwuka, 2005). Functional property could also be the structure/conformation of protein and other food components such as water, carbohydrates, lipids, and vitamins (James, 1995). Proteins are excellent reactants among other food components and reacts with reducing sugars, fats and other oxidation products, phenols and many other food components (Matil, 2010).

According to Okaka (1997), functionality can be regarded as any physicochemical property that affects processing and the behavior of the component in the food product. Functional characteristics play a great role in the determination of the acceptability of flour, protein or paste as an ingredient in preparing foods (Onimawo and Egbekun, 1998). They however depend on some parameters that interact between salts, acids, gums, carbohydrate, fat etc, which affects the final products (Onimawo and Egbekun, 1998). Some of the functional properties or characteristics are; water absorption capacity (WAC), Oil Absorption Capacity (OAC), bulk density, loose density, swelling capacity/index, gelation time, gelation temperature, emulsion capacity etc (Oladunmoye et al., 2014) . Cassava products exhibits several functional properties, the acidity of fermented cassava roots and its products has been found to be caused by the synthesis of lactates, acetates and some volatile organic acids (Oyewole and Odunfa, 1989). The acid contributes to the desirable sourness of garri and an indication of the duration and effectiveness of the fermentation step in garri processing (Oyewole and Odunfa, 1992). The high bulk density of garri increase the rate of dispersion which is important in the reconstitution of flours in hot water to produced dough and the bulk density of fufu is determine by the fraction of weight over the volume (Chimma et al., 2013). 
During fermentation process of fufu mash, the sugar content decreases as the fermenting time increases (Oyewole and Ogundele, 2001). The increasing acidity in cassava fermentation is due to the activities of microorganisms which convert the carbohydrate to organic acids. The amount of starch utilized or converted to sugars and organic acids during cassava fermentation is comparatively low but the product still has a high starch content. Cassava flour level yield clearly caused a volume decrease when use in bread making because of the reduced flour strength and a lower ability of the gluten network to enclose the carbondioxide produced during fermentation (Akingbala et al.,2011). The volume of the settle food particles were used as the index of despersibility (Eke et al., 2008). The flour obtained from dry cassava chips exhibits lower water absorption capacity, oil absorption capacity, high bulk density, swelling index and gelatinization temperature (Ekwu, 2015).

Pasting and crystalline characteristics are important in starch applications and for any successful utilization in food products; the protein should possess a high degree of functionality (Charles et al., 2005; Zeeman, 2002). Some factors such as Genotype, growth season, and growth location all affected the pasting behavior of rice flour (Zeeman, 2002). The pasting behavior of all flours have been seen in research to be influenced by genotype and environmental factors that brought about subtle changes in the source materials such as grains and tubers. Knowledge of pasting properties is often an important indicator of the processing quality of foods and their constituents. Such knowledge is applied by a processor in optimizing ingredient concentrations and temperature-pressure-shear limits to achieve a desired product (Maziya-Dixon et al., 2005). Pasting properties are often assessed from pasting curves obtained using a (a heating and cooling viscometer that monitors the resistance of a sample to controlled shear (Rapid ViscoAnalyserRVA). The pasting behavior of starch-water mixture is influenced by the chemical and physical properties of the sample, including the amount and type of starch, and the presence of lipids, proteins, and low molecular weight solutes (Charles et al., 2005). Peak viscosity, is an index of the ability of starch based foods to swell freely before their physical break down (Sanni et al., 2006). Trough is the minimum viscosity value in the constant temperature phase of the RVA pasting profile and it measures the ability of the paste to withstand break down during cooling (Adebowale et al., 2005). Peak time is a measure of the cooking time and pasting temperature indicates higher water binding capacity, higher gelatinization tendency and lower swelling property of flour (Adebowale et al., 2005; Singh et al., 2003). Final viscosity of flour samples is important in determining the ability of a sample to form a gel during processing (Adebowale et al., 2005). Final viscosity is an indication of whether the starch material forms a gel or a paste on cooling and also indicates the strength of cooked paste (Ofegbayo et al., 2006). Setback is an index of the tendency of the cooked flour to harden on cooling due to amylase retrogradation (Adeniyi et al., 2010). 


\section{MATERIALS AND METHOD}

\section{Material collection}

Some freshly harvested white cassava tuber (Manihot Dulcis Crantz) called "Nwocha" in the South East Zone of Nigeria, and Yellow cassava tuber (Manihot Utilisima Crantz or TMS 01/1368 also called "Umucass"(Plates1A and B) were obtained from the National Root Crops Research Institute, Umudike, Abia State. Other materials for the study were obtained from the Laboratories of the departments of Food Science and Technology and Nutrition and Dietetics of Imo State University, Owerri where the study was carried out.

\section{Processing cassava tubers varieties into selected food products}

Twenty kilogrammes (20kg) of each variety (yellow and white cassava tuber) was used in the study. The tuber varieties were separately peeled, washed and portioned into four (4) for the different desired products (garri, fufu, tapioca and cassava flour).

\section{Functional properties determination of products from the cassava products}

The functional properties were determined as described below;

\section{Water/oil absorption capacity of products from the cassava varieties}

The method of Lin et al (1974) as modified by Onwuka (2005) was employed. The water absorption capacity was expressed as the amount of water absorbed and held by a unit weight of the flour sample.

One gramme $(1 \mathrm{~g})$ of the sample was dispensed into a weighed centrifuge tube. Ten mililitres (10 $\mathrm{ml}$ ) of distilled water was added to the sample and mixed very well. The mixture was allowed to stand for one hour $(1 \mathrm{hr})$ before it was centrifuged at 5,000 rpm $\times \mathrm{g}$ for 30 minutes. The volume of free water or oil (the supernatant) was read directly from the graduated centrifuge tube.

Note; Absorption capacity is expressed as grams of oil or water absorbed (or retained) per gram of sample.

Calculation;

The amount of oil or water absorbed (total minus free) was multiplied by its density for conversion to grams. Density of water is $1 \mathrm{~g} / \mathrm{ml}$ that of oil will vary depending on the type of oil (which can be determined). Bleached palm oil for example has a density of $0.88 \mathrm{~g} / \mathrm{ml}$. The weight of water absorbed was determined by difference.

WAC w/wcg=W_s (g)-W_f (g) -------------------------------Eqn (1)

Where:WAC $=$ Water absorption capacity $(\mathrm{g} / \mathrm{g})$

Ws $=$ Weight of sample sediment $(\mathrm{g})$

$\mathrm{Wf}=$ Weight of sample flour $(\mathrm{g})$

\section{Bulk density of products from the cassava varieties}

Journal of the Faculty of Agriculture and Veterinary Medicine, Imo State University Owerri website: www ajol.info 
The method outlined by Okaka and Potter (1977) as modified by Onwuka (2005) was applied. Fifty grammes $(50 \mathrm{~g})$ of the flour sample each was poured into a hundred millilitres $(100 \mathrm{ml})$ graduated cylinder.

The initial volume (VI) occupied by sample was noted. The cylinder was then taped several times 10-15 times until a constant volume was obtained. The final volume was also noted. The bulk density is expressed as $\mathrm{g} / \mathrm{cm} 3$ of sample.

That is $\mathrm{g} / \mathrm{ml}=($ Weight of sample $(\mathrm{g})) /($ Volume of sample $(\mathrm{ml}))$ or $\mathrm{g} / \mathrm{ml}--------------E q n(14)$

\section{Swelling index of products from the cassava varieties}

The swelling index was determined using the method of Okezie and Bello (1988). It was determined as the ratio of swollen volume of a unit weight of the sample when left in contact with excess water. One gram $(1 \mathrm{~g})$ of the flour sample was dispensed into a calibrated ten mililitres $(10 \mathrm{ml})$ measuring cylinder. Ten mililitres $(10 \mathrm{ml})$ of distilled water was left to stand undisturbed for one hour $(1 \mathrm{~h})$. The volume which the sample occupied was then recorded. The swelling index was determined by calculation as follows

Swelling index $=\mathrm{V}^{\wedge} 2 / \mathrm{V}^{\wedge} 1$ Eqn (15)

Where: $\quad V^{\wedge} 1=$ Initial volume occupied by sample $\mathrm{V}^{\wedge} 2=$ Volume occupied by the sample after swelling

\section{Gelation temperature/time of products from the cassava varieties}

The method modified by Onwuka (2005) was used. One (1) gram of the sample flour was weighed into a beaker containing ten (10) $\mathrm{ml}$ distilled water. The aqueous suspension was heated in boiling water bath with continuous stirring using a thermometer. The gelatinization temperature and time was recorded immediately when gelatinization was noticed.

\section{Solubility of products from the cassava varieties}

The solubility of cassava products were determined by method described by Onwuka (2005). Ten grammes $(10 \mathrm{~g})$ of sample were added into a $250 \mathrm{ml}$ graduated cylinder with a diameter of $1 \mathrm{~cm}$. A finger was placed over the open end of the cylinder, inverted and clamped at a height of $10 \mathrm{~cm}$ from the surface of a $600 \mathrm{ml}$ beaker containing $500 \mathrm{ml}$ of distilled water. The finger was removed to allow the test material to be dumped.

\section{Pasting property of products from the cassava varieties}

The pasting properties of flour and garri samples were determined using a Rapid visco analyser (Model RVA-4, Newport Scientific PVT. Ltd., Australia) following the procedure given in the manual. Three (3) grams of the sample was mixed with twenty five millilitres $(25 \mathrm{ml})$ of distilled water and cooked at $950 \mathrm{C}$ for 3.7 minutes. It was held at this temperature for $2.5 \mathrm{~min}$ and cooled to $500 \mathrm{C}$ where it was again held for two minutes $(2 \mathrm{~min})$. The parameters measured were peak viscosity (PV) (the highest viscosity of the paste during the heating ); hot paste or trough 
viscosity (TV) ( the viscosity of the paste at the end of the heating phase at 950C,) and the cold paste viscosity or the final viscosity (FV) that is, (the viscosity of the paste at the end of the cooling paste at 500C). The other parameters were calculated as the breakdown (BD) viscosity (PV-TV); and set back (SB) Viscosity (FV-TV).

\section{Data Analysis}

All data obtained from four samples each in duplicates were analysed statistically using paired Ttest to compare the paired sample products from white and yellow cassava varieties. The least significant difference was done at $5 \%$ level of significance between means for all the nutritional evaluation.

\section{RESULTS}

\section{The Functional properties of the products from the yellow and white cassava varieties}

Table 1 shows that the water absorption capacities (WAC) of the yellow cassava products were in the range of $2.85 \pm 0.02$ to $4.36 \pm 0.06 \mathrm{~g} / \mathrm{g}$ with yellow cassava tapioca having the least value $(2.85 \pm 0.02 \mathrm{~g} / \mathrm{g})$ and yellow cassava flour having the highest value $(4.36 \pm 0.06 \mathrm{~g} / \mathrm{g})$. The water absorption capacities of the white cassava products were in the range of $2.79 \pm 0.01$ to $4.34 \pm 0.14 \mathrm{~g} / \mathrm{g}$ with white cassava tapioca having the least value $(2.79 \pm 0.0 \mathrm{~g} / \mathrm{g})$ and the white cassava flour having the highest value $(4.34 \pm 0.14)$. Some significant differences $(p<0.05)$ existed between the water absorption capacities value of the match pairs (similar products) of white and yellow cassava varieties, with the exception of the garri samples.

The oil absorption capacities (OAC) of the yellow cassava products were in the range of $1.94 \pm 0.03$ to $2.91 \pm 0.01 \mathrm{~g} / \mathrm{g}$ with yellow cassava tapioca having the least value $(1.94 \pm 0.03 \mathrm{~g} / \mathrm{g}) \mathrm{e}$ and the yellow cassava flour having the highest value $(2.91 \pm 0.01 \mathrm{~g} / \mathrm{g})$. The oil absorption capacities of the white cassava products were in the range of $1.95 \pm 0.01$ to $2.94 \pm 0.10 \mathrm{~g} / \mathrm{g}$ with white cassava tapioca having the least value $(1.95 \pm 0.01)$ and white cassava flour having the highest value $(2.94 \pm 0.10 \mathrm{~g} / \mathrm{g})$. All the match pairs (similar products) of the yellow and white cassava showed significant differences $(\mathrm{p}<0.05)$ in the oil absorption capacity of the cassava product with exception of the tapioca samples. .

The bulk density (BD) value of the yellow cassava products and white cassava products were in the range of $0.48 \pm 0.05$ to $0.54 \pm 0.0 \mathrm{~g} / \mathrm{ml}$ and $0.47 \pm .0 .04$ to $0.55 \pm 0.02 \mathrm{~g} / \mathrm{ml}$ respectively. There was no significant difference $(\mathrm{p}>0.05)$ between all the pair similar products from the yellow and white cassava varieties with regards to the BD.

The swelling index (SI) values of the yellow cassava products were in the range of $2.80 \pm 0.06$ to $3.42 \pm 0.04$ with yellow cassava tapioca having the least value $(2.80 \pm 0.06)$ and yellow cassava flour having the highest value (3.42 \pm 0.04$)$. The Swelling index values of the white cassava products were in the range of $2.75 \pm 0.04$ to $3.38 \pm 0.02$ with white cassava tapioca having the least value $(2.75 \pm 0.04)$ and white cassava flour having the highest value $(3.38 \pm 0.02)$ with the Journal of the Faculty of Agriculture and Veterinary Medicine, Imo State University Owerri website: $w w w$ ajol.info 
exception of the garri product, there were significant difference $(\mathrm{P}<0.05)$ between the match pairs (similar products) of both yellow and white cassava varieties with regards to SI.

The gelation temperatures (GT) of the yellow cassava products were in the range of $63.35 \pm 0.05$ to $81.50 \pm 0.02 \mathrm{oC}$ with yellow cassava tapioca having the least value $(63.35 \pm 0.05)$ and yellow cassava garri having the highest value $(81.50 \pm 0.02)$. The gelation temperature of the white cassava products were in the range of $63.20 \pm 0.04$ to $81.40 \pm 0.02 \mathrm{oC}$ with white cassava tapioca having the least value $(63.20 \pm 0.04)$ and yellow cassava garri having the highest value $(81.40 \pm 0.02)$. Significant differences $(\mathrm{p}<0.05)$ existed between the GT values of the garri samples and values of the tapioca samples but not between the GT values of the flour samples of the varieties. For each of two cassava varieties the garri samples had the GT value $(\approx 81.5)$ among the products studied.

The Solubility values of the yellow cassava products were in the range of $5.48 \pm 0.01$ to $7.49 \pm 0.04$ with yellow cassava garri having the least value $(5.48 \pm 0.01)$ and the yellow cassava flour having the highest value $(7.49 \pm 0.04)$. The solubility values of the white cassava products were the range of $5.71 \pm 0.01$ to $7.61 \pm 0.01$ with white cassava garri having the least value $(5.71 \pm 0.01)$ and white cassava flour having the highest value (7.61 \pm 0.01$)$. All product match pairs (similar products) from yellow and white cassava variety showed some significant differences $(p<0.05)$ between their solubility values though the garri samples from both varieties had the lowest solubility value (5.48-5.71) as compared to values above 7.0 for the other products

\section{The pasting properties of the products from the yellow and white cassava varieties}

Table 2 shows that the Peak viscosity values (RVU) for the yellow cassava products were in the range of $735.50 \pm 16.26$ to $5084.50 \pm 67.18$ with yellow tapioca having the least value

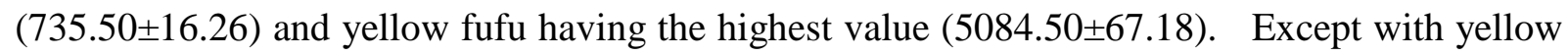
cassava flour and the wheat flour (control). The peak viscosity values of the white cassava products were in the range of $222.00 \pm 2.83$ to $3939.50 \pm 45.96$ with white tapioca having the least value $(222.00 \pm 2.83)$ and white fufu having the highest value (3939.50 \pm 45.96$)$. There were some significant difference ( $p>0.05$ ) between the peak viscosities of each set of similar products of the two cassava varieties, including the wheat flour used as control. But for the flour products where the white variety flour had higher peak viscosity and was closer to the wheat flour value, other yellow cassava products had higher peak viscosity than their marching (similar) products of the white cassava variety.

The Trough viscosity values of the yellow cassava products were in the range of $615.50 \pm 3.54$ to $259.00 \pm 19.09$ with yellow cassava flour having the least value $(615.50 \pm 3.54)$ and yellow fufu having the highest value $(259.00 \pm 19.09)$. The trough viscosity value of the white cassava products were in the range of $184.50 \pm 3.54$ to $1471.00 \pm 35.36$ with white tapioca having the least

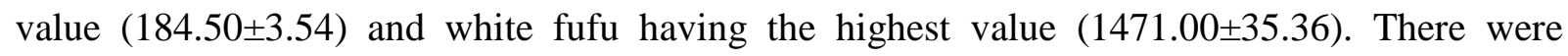
significant difference ( $p>0.05)$ between the Trough viscosity values of each pair similar products from the yellow and white cassava varieties including their flour samples and the wheat flour 
(control). The fufu products had the highest (above 1400) T-viscosity among the varieties products and even so, the yellow cassava fufu had a higher value (2590 unit) compared to a value of 1471 unit of the white cassava.

The breakdown viscosity value s of the yellow cassava products were in the range of $47.50 \pm 2.12$ to $2494.0 \pm 48.08$ with yellow garri having the least value $(47.50 \pm 2.12)$ and yellow fufu having the highest value $(2494.0 \pm 48.08)$. The breakdown viscosity value of the white cassava products were in the range of $26.50 \pm 0.71$ to $2469.5 \pm 81.32$ with white garri having the least $(26.50 \pm 0.71)$ value and white fufu having the highest $(2469.5 \pm 81.32)$ value. Significant differences $(\mathrm{p}<0.05)$ existed between the match pairs (similar products) of yellow and white cassava varieties, with regards their breakdown viscosity with the exception of the fufu products. Also the wheat flour (control) showed significant difference with the cassava flour samples.

The final viscosity of the yellow cassava products were in the range of $989.50 \pm 2.12$ to $3500.50 \pm 44.55$ with yellow cassava flour having the least value $(989.50 \pm 2.12)$ and yellow fufu

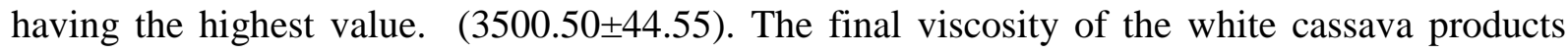
were in the range of $486.50 \pm 6.36$ to $2222.50 \pm 19.09$ with white tapioca having the least value (486.50 \pm 6.36$)$ and white fufu having the highest value $(2222.50 \pm 19.09)$. there were significant differences $(p>0.05)$ between each set of similar products of the varieties with regards to their final viscosities, the wheat flour (control) inclusive. But for the flour product where the white cassava flour had higher (1595) F-viscosity than the yellow cassava flour (989) for all other sets of similar products studied the yellow cassava product had higher F-viscosities than their similar white cassava product. Also the fufu product (irrespective of cassava variety) had the highest Fviscosity values among the studied products and even so, the yellow cassava fufu had the overall highest value (3500 unit).

The set-back viscosity values of the yellow cassava products were in the range of $374.00 \pm 1.41$ to $967.00 \pm 12.73$ with yellow cassava flour having the least value $(374.00 \pm 1.41)$ and yellow garri having the highest value $(967.00 \pm 12.73)$. The set-back viscosity values of the white cassava products were in the range of $302.00 \pm 2.82$ to $764.00 \pm 48.08$ with white tapioca having the least

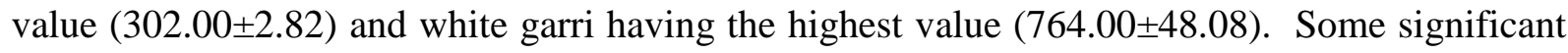
differences $(\mathrm{p}<0.05)$ existed between the set-back viscosity values of all the match pairs (similar products) of both yellow and white cassava including the flour samples in wheat flour. Among the experimental samples (products) the white cassava tapioca had the lowest set-back viscosity (302) while the yellow cassava tapioca had the highest value (989).

The peak-time viscosity values of the yellow cassava products were in the range of $3.73 \pm 0.00$ to $7.00 \pm 0.00$ with yellow cassava flour having the least value $(3.73 \pm 0.00)$ and yellow tapioca having the highest value $(7.00 \pm 0.00)$. The peak time viscosity values of the white cassava products were in the range of $3.70 \pm 0.42$ to $6.97 \pm 0.05$ with the white cassava fufu having the least value (3.70 \pm 0.42$)$ and white garri having the highest value $(6.97 \pm 0.05)$. Significant differences $(p<0.05)$ existed between the peak time viscosity values of the match pairs (similar 
products) of cassava fufu and cassava flour of the varieties but not between their garri samples or their tapioca samples.

The pasting temperatures of the yellow and white cassava products were in the ranges of $50.73 \pm 0.67$ to $77.98 \pm 1.94$ for yellow cassava products and $0.00 \pm 0.00$ to $89.13 \pm 0.06$ for white cassava products. All match pairs (similar products) of cassava products showed significant differences $(p<0.05)$ in their pasting temperature with the exception of the cassava fufuf products. Both the yellow and white cassava variety flour differed significantly $(\mathrm{p}<0.05)$ from wheat flour (control).

\section{DISCUSSION}

\section{The functional properties of products from yellow and white cassava tuber varieties.}

Among the studied finished cassava products, the fermented cassava flour had the highest water absorption capacity (WAC) $4.4 \mathrm{~g} / \mathrm{g}$ as compared to values of $3.75 \mathrm{~g} / \mathrm{g}$ for garri and $2.85 \mathrm{~g} / \mathrm{g}$ for tapioca (Table 1). It was observed that there were no significant differences $(p>0.05)$ in the WAC of similar products from the two varieties except the garri products. Though, the samples could require different quantity of water during reconstitution; this could be as a result of different degree of protein constituents. This view is in line with the report of Chimma et al. (2014) that water absorption capacity depended on the amount and nature of hydrophilic constituents, and to some extent on protein. Water absorption capacity is the ability of the flour particle to entrap and hold water such that exudation is prevented (Chen and Liu, 2002). Furthermore, as reported by Adebowale, et al (2005), cassava has the highest reconstitution ability than other flour samples (Chen and Liu, 2002). Water absorption capacity is important in bulking and consistency of products as well as in baking applications as high absorption capacity may assure products cohesiveness (Lorenz and Collins, 1990).

The oil absorption capacity (OAC) values of the studied varieties and products showed significant differences $(\mathrm{p}<0.05)$ in all similar pair of products except tapioca. Thus; the tapioca samples had the lowest OAC with a mean value of $1.95 \mathrm{~g} / \mathrm{g}$ while the garri and flour products had mean OAC values of $2.9 \mathrm{~g} / \mathrm{g}$. The two cassava tuber varieties and their similar (corresponding) products had similar values for the OAC. The result obtained in the study differs from that of Oladunmoye et al. (2014) that the oil absorption capacity (OAC) for $100 \%$ wheat flour was $1.83 \mathrm{ml} / \mathrm{g}$. The variation in the oil absorption capacities of the samples could be as a result applied heat during the processing operations. This was also an indication that cassava root is mainly a carbohydrate source and not among the oil seeds (Perez and Gonzales, 1997). Furthermore, Hutton and Campbell, (1991) reported that the ability of food to absorb oil may help to enhance sensory properties such as flavor retention. Leszezynski , (1989) suggested that flour samples with higher oil absorption capacity will have a higher potential for physical entrapment of oil and the binding of fat to polar chains of protein, following application of filtration and pressure of centrifugation. The higher $2.91 \mathrm{~g} / \mathrm{g}$ and $2.94 \mathrm{~g} / \mathrm{g}$ values for flour samples 
suggested the presence of lipophilic constituent and that such flour samples can be suitable for use in food production (Arinola, 2014). Since this property is important in the production of meat extenders, doughnuts, baked goods and soups as they enhance flavor and improve mouth feel (Hutton and Campbell, 1991).

The bulk densities (BD) of all the similar product pairs, showed no significant difference ( $>0.05$ ) and the bulk density of studied samples ranged from $0.47 \mathrm{~g} / \mathrm{ml}$ (tapioca) to $0.55 \mathrm{~g} / \mathrm{ml}$ (flour). The flour samples, had no significant difference $(\mathrm{p}>0.05)$ between their BD values, although their values were higher than those of other products studied. This might be because, flour when compared to boiled and dried tapioca or fried garri, the samples had less particle size and better, packing than, the coarse looking garri and ground gritty tapioca. Bates, (2002) reported that a bed of fine particles will compact with loading as the packing order of the particles is disturbed. More so bulk density is a reflection of the load the flour sample can carry. Singh et al. (2003) stated that the lower the bulk density, the higher the amount of flour that could give space and thus reduce packaging cost. The densities of processed products dictate the characteristics of their containers since the packaged product density influences the amount and strength of packaging material, texture or mouth feel (Lewis, 1990). According to Perez and Gonzales, (1997), higher bulk density is desirable for greater ease of dispensability of flours. The result from this study is different from the report of Bates (2002) which indicated a value of $0.619 \mathrm{~g} / \mathrm{cm} 3$ for $100 \%$ wheat flour. Also Adeleke and Odedeji (2010) reported a bulk density of $7.47 \mathrm{~g} / \mathrm{cm} 3$ for wheat flour. Hence, increase in bulk density increases the sinkability of powdered particles which in turn aids wetting by aiding their ability to disperse.

There were no significant differences $(p>0.05)$ in the swelling index (SI) values of similar product pairs from the two varieties except tapioca and flour. Thus, the mean SI values in garri samples had S.I. was about 3.2\%, in the tapioca samples $2.8 \%$ and the flour samples $3.4 \%$. These data indicated that the two tuber varieties are identical in this property. The swelling index of starch granules is dependent on the affinity of starch molecules for water molecules (Achuonye, 1985). Moorthy and Ramanujam, (1986) suggested that the swelling power of granules reflected the extent of the association forces within the granule. The little relative differences between similar products in their SI of the varieties could be due to the maturity and varietal differences. This is different from a value of $2.36 \%$ was reported by Bates (2002) for 100\% wheat flour. Swelling index is a function of the starch content and the degree of gelatinization of garri is reflected in its swelling properties when in water. High swelling index has been reported as part of the criteria for a good quality cassava product (Achinwehu et al., 1998). Also, Moorthy and Ramanujam, (1996) suggested that the swelling power of granules reflected the extent of the association forces within the granules.

Significant differences $(\mathrm{p}<0.05)$ in the gelation temperature were observed in all similar product pairs except in cassava flours. The garri product for both varieties had higher gelation temperature than the tapioca and fermented flour products, while the garri samples had mean gelation temperature of $81.50 \mathrm{C}$, the tapioca and flour samples had an average gelation 
temperature of $63.90 \mathrm{C}$. The gelatinization temperature increased in garri due to exposure to heat processing. The gelatinization temperature of the cassava products differed from the findings of Bates (2002) for grain products $\left(62^{\circ} \mathrm{C}\right.$ for $100 \%$ wheat flour, $59.72 \circ \mathrm{oC}, 57.58 \mathrm{oC}$ and $62.36 \mathrm{oC}$ for potato, rice and grain flours respectively. The differences could be attributable to processing methods, species of cultivar, growing environment and maturation ability of the cultivar. The, gelatinization temperature is the temperature at which the starch absorbs water and swell; and it determines the amount of time it takes for a particular variety of food to cook (Adebowale et al., 2005; Chimma et al., 2013). Adebowale et al. (2005) reported that foods with low gelatinization temperature indicated that the food granules resist swelling.

The solubility of all similar pairs of product from the two varieties showed significant difference $(\mathrm{p}<0.05)$. The mean solubility value of tapioca and flour samples were higher (mean value $X$ $7.4 \%)$ than the mean solubility values $(5.6 \%)$ of the garri samples of the two varieties. The observed lower solubility in garri value might be attributed to larger coarse particles of garri with consequent smaller surface area for water absorption when compared to tapioca grits and fine fermented cassava flour particles. Solubility is a function of ease of dispersion in water and the sample with the lowest solubility dissolves less in water (Bates, 2002).

\section{Pasting properties of products from yellow and white cassava varieties}

The peak viscosity values of all product samples studied ranged from 222 RVU (For White tapioca sample) to 5084RVU (Yellow fufu sample). Significant differences $(\mathrm{P}<0.05)$ existed between all similar pairs of products from the yellow and white cassava varieties and the control. In each of the cassava varieties, the fufu products sample had the highest peak viscosity value among its other product samples (Table 4.1). Specifically, Yellow cassava fufu flour had the highest peak viscosity value of 5084.50 RVU as compared to a value of 1018.50 RVU for yellow garri and 735.50RVU for its yellow tapioca while white cassava fufu flour had a value of 3939.50RVU as compared to 547.00RVU for white garri and a value of $222.00 \mathrm{RVU}$ for white tapioca. The reference wheat flour (control) had a value of $2152.0 \mathrm{RVU}$ which is far below the observed value for the fufu products from each of the varieties but higher than the values (5471018RVU) for the garri, (222-735RVU) for tapioca and (1685-2118RVU) for cassava flour products. Thus, in a food formulation where high peak viscosity is preferred, the fufu flour provides a better choice of ingredient. In each cassava variety, the tapioca samples had the least values 184-617RVU for trough viscosity, followed by the garri samples (520-971RVU), among the products studied. Specifically, the yellow fufu sample had a trough viscosity value of 2590.50RVU. Its tapioca had a value of $617.50 \mathrm{RVU}$ while its plain flour had a value of 615.50RVU (Table 4.1). On the other hand, the white cassava fufu product had a value of 1471.00RVU. Its garri and tapioca had values of 520.50, $184.50 \mathrm{RVU}$ respectively and its plain flour had a value of 1079.00RVU. These values are all lower than 1299.50RVU observed for the control wheat flour except values for fufuproducts (1471.00 -2590.50RVU). These data suggested that the period of fermentation (48hr as applied in fufu processing) enhanced fufu cassava products more than the other products, with regards to trough viscosity. With respect to 
this property the performance of products from yellow cassava varieties was higher than the white cassava products though all the products had trough viscosity values lower than (<1299.50RVU) that of wheat flour except the fufu sample products (1471.00-2590.50RVU). The breakdown viscosity values of all the cassava products studied ranged from 26.50RVU (white garri) to 2494.99RVU (yellow fufu). Significant differences $(p<0.05)$ were observed in the break down viscosity value of similar pairs of all the products except in fufu products. Among the product samples studied, the garri products (irrespective of variety) had the lowest (26.50 and 47.50 RVU) breakdown viscosity values and the fufu products had the highest (2468.50 and 2494.00RVU) breakdown values for white and yellow fufu respectively. The white and yellow cassava flour had values of 1037.50 and 1069.50 RVU respectively, all these being higher than a value of $852.50 \mathrm{RVU}$ observed for the control wheat flour. This suggested that the fermentation and drying treatments applied in fufu and flour processing might have induced higher breakdown viscosity in these particular products. More so, the flour from the wheat (cereals) and flour from cassava tubers do not have the same chemical and nutritional constituents. The final viscosity values of the product samples ranged from $486.50 \mathrm{RVU}$ (white tapioca) to $3500.50 \mathrm{RVU}$ (yellow fufu product). Significant differences $(p<0.05)$ were observed in the similar product pairs with respect to final viscosity. The fufu products had the highest 2222.50-3500.50RVU values for white and yellow fufu respectively compared to the other products including the control (2859.0RVU). Fermentation and enzymatic breakdown during fufu processing caused highest final viscosity values in fufu than the other products and even the control. The set-back viscosity values for the cassava product samples ranged from 302.00RVU (white tapioca) to 989.50RVU (yellow tapioca). Significant differences $(\mathrm{p}<0.05)$ were observed in the similar products for set-back viscosity except in fufu products. In all products (treatments samples) studied, the yellow cassava samples had higher set-back viscosity values than their corresponding (matching products) from the white variety. For instance, while the yellow tapioca product had a set-back viscosity of 989.50RVU,the white tapioca counter -part had a value of 302.00RVU.Also while the yellow garri sample had a value of 967.00 RVU, its white counterpart had a value of $764.00 \mathrm{RVU}$ ), the same trend was followed for yellow (910.00 RVU) and white (751.50 RVU) fufu products. However, this trend went contrary in the plain cassava flours (374.00 and 514.00 RVU) for yellow and white flours. As observed, the reference wheat flour had a higher (1559.50RVU) set back viscosity value, more than every other product studied, irrespective of the cassava variety considered. However, there was significant difference $(p<0.05)$ among all the products studied with respect to set- back viscosity. The garri products of the two varieties (Yellow and white cassava) had no significant difference ( $p>0.05)$ than in the peak time values obtained. Peak-time values ranged from $3.70-7.00 \mathrm{~min}$ for white fufu and yellow tapioca. The tapioca products had the highest 6.94-7.00min peak time among all studied products including the wheat flour (Control with 6.20min). However, the cassava flour and fufu samples had lower peak-time values of 3.73- 4.04 minutes and 3.70-4.27 minutes respectively among other product samples studied. Statistical differences $(p<0.05)$ were observed between the Control (wheat sample), the garri, and the tapioca products. The heat treatment (boiling) and 
soaking involved in tapioca and garri processing might have softened the tissues to attain peak time quickly, though they took more time to get to their final viscosities. However, the drying operation in flours processing might have led to higher peak time attainment and hence more energy needed, with less time to get to final viscosity. Significant differences $(p<0.05)$ were observed in the pasting temperatures of all the samples studied except in fermented fufu product pairs. The white tapioca product sample had the least pasting temperature $(0.000 \mathrm{C})$ while the white garri had the highest pasting temperature (89.130C). Wheat flour (Control) had a pasting temperature of 88 . 200C which was lower than the values observed for white garri but higher than those of the other studied cassava products. The heat treatment (toasting) during garri processing induced it to higher pasting temperature. There was no significant differences ( $>0.05$ ) in pasting temperatures of the fufu products $(72.100 \mathrm{C}$ and $73.830 \mathrm{C}$ ) from the two cassava varieties but, significant differences $(\mathrm{p}<0.05)$ were observed in all other studied similar product pairs.

\section{CONCLUSION}

Considering the peak viscosity, trough viscosity, peak time and pasting temperature of the varietal flour samples, the white cassava flour had values closer to those of wheat flour than the yellow cassava variety. However, the yellow cassava tuber products were accepted but respondents preferred their usual white products than the yellow products without considering their nutritional and health prospects. 


\section{REFERENCES}

Adebowale A.A, L .O. Sanni, Awonorin S.O (2005). Effect of texture modifiers on the physicochemical and sensory properties of dried fufu. Food Sci. Technol. Inter, 11:37385.

Adeniji, T.A., Hart, A.D., Tenkouano, A., Barimakg I.S., and Sanni L.O. (2010). Comparative study of Pasting Properties of improved Plantain, Banana and Cassava varieties with emphasis on Industrial Application Africa Journal of food, Agriculture, Nutrition and Development.Vol.10 (5).

Benesi, I.R.M, M.T. Labuschargne, A. G.O. Dixon and N.M. Mahungu, (2004) Genetypex Environment interaction effects on native cassava starch quality and potential for starch in the commercial sector African crop science journal 12:205-216.

Charles AL, Chang YH, Ko WC, Sriroth K, and Huang TC.( 2004). Some physical and chemical properties of starch isolates of cassava genotypes. Starch/Starke 56:413-8.

Charles AL, Sriroth K, and Huang TC. (2005). Proximate composition, mineral contents, hydrogen cyanide and phytic acid of 5 cassava genotypes. Food Chem 92:615-620. http//dx-doi.org/10.1016(foodchem200408.024).

Chung, H. J.' Shin D.H. and Lim. S.T (2008). In vitro starch digestibility and estimated glycemic index of chemical modified corn starches. Food Res Int. 41:579-585.

Eke, J. (2006). Chemican, functional and pasting properties of starch and tapioca produced from selected hybrid cassava (Manihotesculentacrantz) cultivars. PHD Thesis, Rivers State University of Science and Technology, Port Harcourt, Nigeria.

Eke- Ejiofor, J. and Owuno, F.(2012).Functional and Pasting Properties of wheat-three leaved yam (Dioscoreadumentorum) composite flour blend. Global Research Journal of Agricultural and biological sciences, 3:330-335.

FAOSTAT (2008).Adaptation of cassava in African Journal of Agricultural Research, 6(28) www.faostat Fao.org.

Ikereogu J.E.G. and Mbah, E.U. (2007).Productivities of Cassava/Okra Intercropping System as Influenced by Okra Planting density. African J. Agric. Res. 2: 223-231

International Institute of Tropical Agriculture (IITA) (2013) Nigeria releases improved cassava varieties to boost productivity news archeive. Ibadan 20000.

Maziya-Dixon, A. A. Adebowale, O. O, Onabanjo and A. G. O. Dixon, (2005).Effectof variety and drying methods of physico-chemical properties of high quality cassava flour from yellow cassava roots. Proc. 7th African Crop Science Conference 2005, p 635-641. 
Nwancho, S.O, Ekwu, F.C. Mgbeagbu P.O. Njoku, C.K. and Okoro, C. (2014).Effect of particle size on the formational, pasting and textural properties of Garri produced from fresh cassava roots and Dry chops. The International Journal of Engineering and Science, 3 (3) $50-55$

Oduro, K. A (1984). Some characteristic of yellow pigmented cassava in 1st Triennial syrup of the international society for Tropical roots crops African Branch (ISTRCAB).Ibadan,Nigeria.8-12 Sept,1980 (ed) E.D. Terry,K.A and Oduro, F Caveness.pp 4244 Ottawa Canada.IDRC.

Ofegbayo B.O., Aina, J.O., Asiedu R. and Bokanga.M. (2006). Pasting characteristics of freshyam (Dioscureaspp) as indicator of food textural quality in a major yam food product pounded yam food chemistry. 99; 663

Raja,K.C.M. and Ramakrishna S.V. (1990). Compositional and pasting characteristic of plain Dried and parboiled cassava (Manihot esculenta Crantz).Food chemistry 38:79-88.

Sanni O.L, A.A., Adebeowade, T.A. Filani, O.B. Oyewole and A. Websty (2006). Quality of flash and rotary dried fufu flour. J. Food Agric. Environ. 4:74-78

Singh, N., Singh J., Kaur, L., Sodhi, N. S. and Gil, S.B. (2003). Thermal and Rheological properties of starches from different botanical sources. Food chemistry, 81:219-231.

Thomas, D.J. and W.A Atwell, (1999) starches practical guides for the food industry. Eagan. Press Itandbooksenes Eagan, St Paul Mininestata, USA pp. 94

Thompson, T., Dennis M. Higgins, L.A. Lee, A.R Sharett M. K. (2005). Gluten -free diet surveys are Americans with coewac Disease consuming recommended amount of fibre, Iron, calcium and grain foods (cassava). Journal of Human Nutrition and Dietetian 18(3):163-169.

Zeeman (2002). Properties of Cassava. Journal of Agric, 45: 8-11

Journal of the Faculty of Agriculture and Veterinary Medicine, Imo State University Owerri website: www ajol.info 
Table 1. Values of functional properties of the products from the yellow and white cassava varieties

\begin{tabular}{|c|c|c|c|c|c|c|c|}
\hline Sample & Parameter & WAC $(g / g)$ & OAC $(g / g)$ & $\mathrm{BD}(\mathrm{g} / \mathrm{ml})$ & SI & GT & Solubility \\
\hline $\begin{array}{l}\text { Yellow } \\
\text { Garri }\end{array}$ & Cassava & $3.73 a \pm 0.01$ & $2.85 b \pm 0.10$ & $0.49 a \pm 0.12$ & $3.16 \mathrm{a} \pm 0.04$ & $81.50 \mathrm{a} \pm 0.02$ & $5.48 b \pm 0.01$ \\
\hline $\begin{array}{l}\text { White } \\
\text { Garri }\end{array}$ & Cassava & $3.75 \mathrm{a} \pm 0.04$ & $2.90 \mathrm{a} \pm 0.11$ & $0.49 \mathrm{a} \pm 0.15$ & $3.15 \mathrm{a} \pm 0.01$ & $81.40 \mathrm{~b} \pm 0.02$ & $5.71 \mathrm{a} \pm 0.01$ \\
\hline $\begin{array}{l}\text { Yellow } \\
\text { Tapioca }\end{array}$ & Cassava & $2.85 \mathrm{a} \pm 0.02$ & $1.94 \mathrm{a} \pm 0.03$ & $0.48 \mathrm{a} \pm 0.05$ & $2.80 \mathrm{a} \pm 0.06$ & $65.35 \mathrm{a} \pm 0.05$ & $7.16 b \pm 0.04$ \\
\hline $\begin{array}{l}\text { White } \\
\text { Tapioca }\end{array}$ & Cassava & $2.79 \mathrm{~b} \pm 0.01$ & $1.95 \mathrm{a} \pm 0.01$ & $0.47 \mathrm{a} \pm 0.04$ & $2.75 b \pm 0.04$ & $63.20 \mathrm{~b} \pm 0.04$ & $\begin{array}{r}7.20 \mathrm{a} \\
\pm 0.06\end{array}$ \\
\hline $\begin{array}{l}\text { Yellow } \\
\text { flour }\end{array}$ & cassava & $4.36 \mathrm{a} \pm 0.06$ & $2.91 b \pm 0.01$ & $0.54 \mathrm{a} \pm 0.04$ & $3.42 \mathrm{a} \pm 0.04$ & $7.49 b \pm 0.04$ & $7.49 b \pm 0.04$ \\
\hline \multicolumn{2}{|c|}{ White cassava flour } & $4.34 \mathrm{~b} \pm 0.14$ & $2.94 a \pm 0.10$ & $0.55 a \pm 0.02$ & $3.38 \mathrm{~b} \pm 0.02$ & $63.63 \mathrm{a} \pm 0.03$ & $7.61 \mathrm{a} \pm 0.01$ \\
\hline
\end{tabular}

Mean scores with same superscript within the same column are not significantly different $(\mathrm{p}<0.05)$.

Keys;

WAC - Water Absorption Capacity, OAC-Oil Absorption Capacity,

BD - Bulk density

SI - Swelling Index

GT - Gelation Temperature

S - Solubility 
Journal of Agriculture and Food Sciences

Volume 17 Number 1, April 2019 pp

$1-1.7$

Table 2: The pasting properties of the products from the yellow and white cassava varieties

\begin{tabular}{|c|c|c|c|c|c|c|c|}
\hline $\begin{array}{l}\text { Cassava } \\
\text { based } \\
\text { Product }\end{array}$ & $\begin{array}{l}\text { PViscosity } \\
\text { RVU }\end{array}$ & $\begin{array}{l}\text { T } \\
\text { Viscosity }\end{array}$ & $\begin{array}{l}\text { B } \\
\text { Viscosity }\end{array}$ & F Viscosity & $\begin{array}{l}\text { S } \\
\text { Viscosity }\end{array}$ & PKT(min) & $\begin{array}{l}\text { PTemper } \\
{ }^{\circ} \mathrm{C}\end{array}$ \\
\hline Yellow Garri & $1018.50^{\mathrm{a}} \pm 64.35$ & $\begin{array}{l}971.00^{\mathrm{a}} \pm \\
62.23\end{array}$ & $\begin{array}{l}47.50^{\mathrm{a}} \pm \\
2.12\end{array}$ & $\begin{array}{l}1938.00^{\mathrm{a}} \pm \\
49.50\end{array}$ & $\begin{array}{l}967.00^{\mathrm{a}} \pm \\
12.73\end{array}$ & $6.27^{\mathrm{a}} \pm 0.94$ & $50.73^{\mathrm{b}} \pm 0.67$ \\
\hline White Garri & $547.00^{\mathrm{b}} \pm 18.39$ & $\begin{array}{l}520.50^{\mathrm{b}} \pm \\
19.09\end{array}$ & $\begin{array}{l}26.50^{\mathrm{b}} \pm \\
0.71\end{array}$ & $\begin{array}{l}1284.50^{\mathrm{b}} \pm \\
67.18\end{array}$ & $\begin{array}{l}764.00^{\mathrm{b}} \pm \\
48.08\end{array}$ & $6.97^{\mathrm{a}} \pm 0.05$ & $89.13^{\mathrm{a}} \pm 0.06$ \\
\hline Yellow fufu & $5084.50^{\mathrm{a}} \pm 67.18$ & $\begin{array}{l}2590.50^{\mathrm{a}} \\
\pm 19.09\end{array}$ & $\begin{array}{l}2494.00^{\mathrm{a}} \pm 4 \\
8.08\end{array}$ & $\begin{array}{l}3500.50^{\mathrm{a}} \pm 4 \\
4.55\end{array}$ & $\begin{array}{l}910.00^{\mathrm{a}} \pm \\
25.46\end{array}$ & $4.27^{\mathrm{a}} \pm 0.00$ & $72.10^{\mathrm{a}} \pm 0.57$ \\
\hline White fufu & $3939.50^{\mathrm{b}} \pm 45.96$ & $\begin{array}{l}1471.00^{\mathrm{b}} \\
\pm 35.36\end{array}$ & $\begin{array}{l}2468.50^{\mathrm{a}} \pm 8 \\
1.32\end{array}$ & $\begin{array}{l}2222.50^{\mathrm{b}} \pm \\
19.09\end{array}$ & $\begin{array}{l}751.50^{\mathrm{b}} \pm 1 \\
6.23\end{array}$ & $3.70^{\mathrm{b}} \pm 0.42$ & $73.83^{\mathrm{a}} \pm 0.67$ \\
\hline $\begin{array}{l}\text { Yellow } \\
\text { tapioca }\end{array}$ & $735.50^{\mathrm{a}} \pm 16.26$ & $\begin{array}{l}617.50^{\mathrm{a}} \pm \\
17.68\end{array}$ & $\begin{array}{l}118.00^{\mathrm{a}} \pm \\
1.41\end{array}$ & $\begin{array}{l}1607.00^{\mathrm{a}} \pm \\
42.43\end{array}$ & $\begin{array}{l}989.50^{\mathrm{a}} \pm 2 \\
4.75\end{array}$ & $7.00^{\mathrm{a}} \pm 0.00$ & $77.98^{\mathrm{a}} \pm 1.94$ \\
\hline White tapioca & $222.00^{\mathrm{b}} \pm 2.83$ & $\begin{array}{l}184.50^{\mathrm{b}} \pm \\
3.54\end{array}$ & $37.50^{\mathrm{b}} \pm 0.71$ & $\begin{array}{l}486.50^{\mathrm{b}} \pm \\
6.36\end{array}$ & $302.00^{\mathrm{b}} \pm 2.82$ & $\begin{array}{l}32 \quad 6.94^{\mathrm{a}} \pm \\
0.09\end{array}$ & $0.00^{\mathrm{b}} \pm 0.00$ \\
\hline $\begin{array}{l}\text { Yellow } \\
\text { cassava Flour }\end{array}$ & $1685.00^{\mathrm{b}} \pm 28.24$ & $\begin{array}{l}615.50^{\mathrm{b}} \pm \\
3.54\end{array}$ & $\begin{array}{l}1069.50^{\mathrm{a}} \pm 2 \\
4.75\end{array}$ & $\begin{array}{l}989.50^{\mathrm{b}} \pm \\
2.12\end{array}$ & $\begin{array}{l}374.00^{\mathrm{b}} \pm \\
1.41\end{array}$ & $3.73^{\mathrm{b}} \pm 0.00$ & $71.75^{b} \pm 0.70$ \\
\hline $\begin{array}{l}\text { White cassava } \\
\text { Flour }\end{array}$ & $2118.50^{\mathrm{a}} \pm 2.12$ & $\begin{array}{l}1079.00^{\mathrm{a}} \\
\pm 7.07\end{array}$ & $\begin{array}{l}1037.50^{\mathrm{b}} \pm \\
2.12\end{array}$ & $\begin{array}{l}1595.00^{\mathrm{a}} \pm \\
11.31\end{array}$ & $\begin{array}{l}514.00^{\mathrm{a}} \pm \\
15.56\end{array}$ & $4.04^{\mathrm{a}} \pm 0.05$ & $74.28^{\mathrm{a}} \pm 0.04$ \\
\hline $\begin{array}{l}\text { Wheat } \\
\text { flour/control }\end{array}$ & $2152.00^{c} \pm 35.36$ & $\begin{array}{l}1299.50^{\mathrm{c}} \\
\pm 20.51\end{array}$ & $\begin{array}{l}852.50^{c} \pm 14 \\
.85\end{array}$ & $\begin{array}{l}2859.00^{c} \\
\pm 42.42\end{array}$ & $\begin{array}{l}1559.50^{\mathrm{c}} \pm \\
21.92\end{array}$ & $6.20^{\mathrm{a}} \pm 0.00$ & $88.20^{c} \pm 0.35$ \\
\hline
\end{tabular}

Mean scores among similar varietal products along the column, that is followed by the same superscript are not significantly different $(\mathrm{p}<0.05)$.

Keys;

Pv-Peak Viscosity

TV-Trough Viscosity

BV-Breakdown Viscosity

FV-Final Viscosity

SV-Set back

PKT-Peak time

PT-Pasting Temperature

Journal of the Faculty of Agriculture and Veterinary Medicine, Imo State University Owerri website: www ajol.info 